\title{
Recent Knowledge of Facial Plastic and Reconstructive Surgery
}

\author{
Il Gyu Kang \\ Department of Otolaryngology-Head \& Neck Surgery, Gil Medical Center, Gachon University Medical School, Incheon, Korea
}

\section{안면 성형 재건의 최신 지견}

강 일 규

가천대학교 길병원 이비인후-두경부외과학교실

\author{
Received December 23, 2014 \\ Revised January 20,2015 \\ Accepted February 15, 2015 \\ Address for correspondence \\ Il Gyu Kang, MD \\ Department of Otolaryngology- \\ Head \& Neck Surgery, \\ Gil Medical Center, \\ Gachon University Medical School, \\ 21 Namdong-daero 774beon-gil, \\ Namdong-gu, Incheon 405-760, \\ Korea \\ Tel $+82-32-460-3765$ \\ Fax +82-32-467-9044 \\ E-mail eyik@naver.com
}

Performance of facial aesthetic surgeries except rhinoplasty in otorlarygoloic department is not usual in South Korea. However, otolaryngologic doctors have been performing facial surgeries, thus, their knowledge of facial surgical anatomy is better than that of other doctors. For this reason, otolaryngologic doctors should study hard in order to learn about performance of facial aesthetic surgeries. Recently, in South Korea, because many facial aesthetic surgeries have been performed, many complications have been reported and facial aesthetic surgery techniques have been developed rapidly. Herein, I would like to introduce some facial aesthetic and reconstructive techniques that are not usually performed in the otolaryngologic department in South Korea. Korean J Otorhinolaryngol-Head Neck Surg 2015;58(6):378-88

\section{서 론}

코성형술 시행시 다른 안면성형수술을 함께 시행하면 환 자의 만족도가 높아지는 경향이 있으나 아직까지 한국에서 는 이비인후과에서 코성형 이외에 안면성형을 시행하는 것이 익숙하지 않은 것이 현실이다. 이비인후과의 특성상 안면질 환이나 안면수술이 많아 안면해부에 익숙하지만 아직까지 이비인후과에서 안면성형 및 재건수술이 활발하게 이루어지 고 있지 않다. 그러나 미국 등 다른 나라에서는 이비인후과 에서 안면성형재건을 담당하고 활발하게 안면성형재건수술 을 시행하고 있다. 안면성형수술 특히 지방주입술, 보톡스, 필러 시술은 그 술기가 복잡하지 않고 심각한 합병증이 상대 적으로 적으며, 환자의 만족도도 높다. 최근에 많은 안면성형 수술이 국내에서 시행됨에 따라 그 시술의 방법도 다양해지 고 발전되었으나 다른 한편으로는 많은 합병증이 보고되기 도 한다. 이에 안면성형재건수술을 시행함에 그 기본적인 원
칙과 최근에 시도되는 방법들을 소개하고자 한다.

$$
\text { 이마거상술 }
$$

나이가 들어가면서 이마에 주름이 생기고 눈썹이 처지는데 이러한 징후는 나이가 젊은 때에도 나타나기도 한다. 이러한 이마 변화를 이마거상술을 시행하여 호전시킬 수 있는데 이 마거상술에는 개방형 이마거상술과 내시경을 이용하여 시행 하는 이마거상술이 있으며 최근에는 내시경을 이용한 이마 거상술이 선호되는 추세이다.

\section{개방형 관상 이마거상술}

관상절개를 하는 개방형 이마거상술의 경우에는 모발 뒤쪽 $3 \sim 4 \mathrm{~cm}$ 후방에 모낭에 평행하게 절개를 시행하여(Fig. 1A), 흉터를 보이지 않게 한다는 장점이 있고, 이 절개방법을 통해 서는 미간주름과 이마주름을 개선할 수 있었다. 그러나 합병 


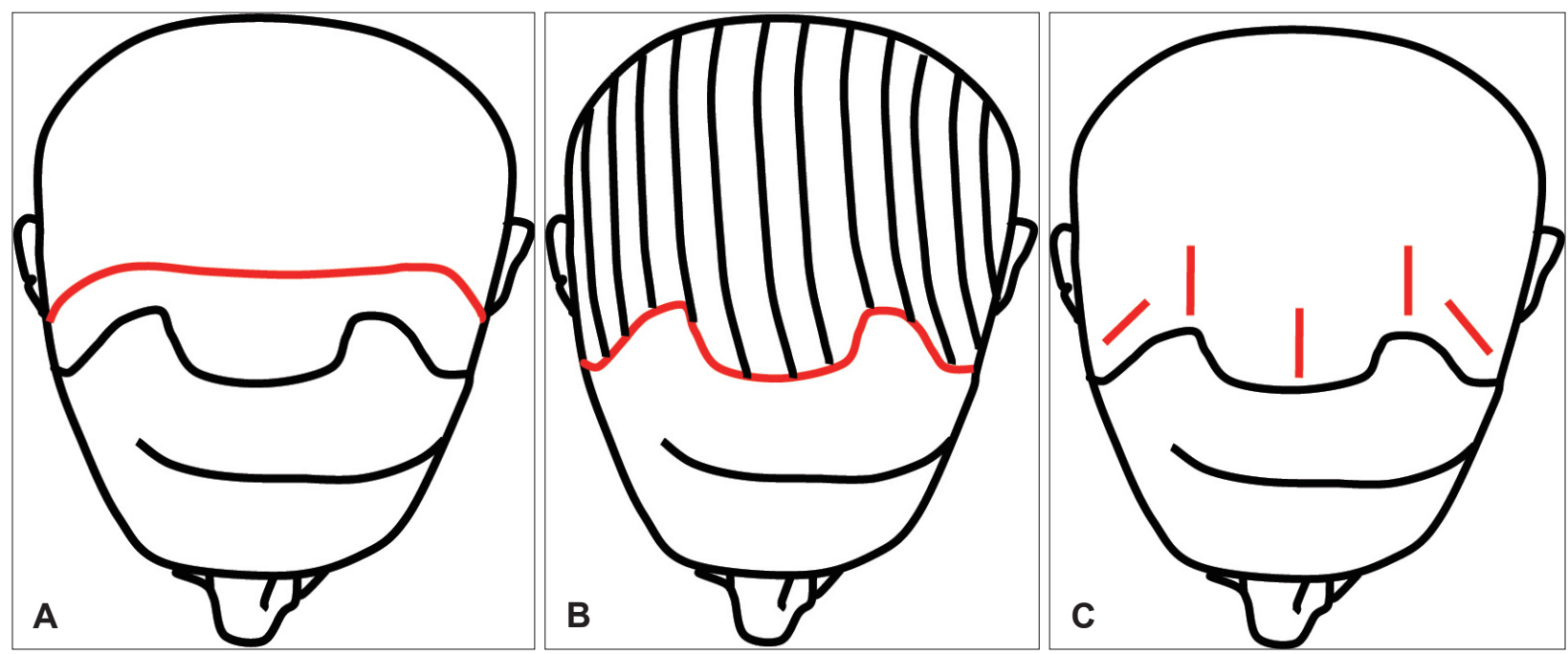

Fig. 1. These images show the bicoronal incision (A), pretrichial incision (B), and incisions made for an endoscopic forehead lift (C).

증으로 혈종, 신경손상으로 인한 감각이상, 흥터, 절개선 부 위 모발의 소실이 있을 수 있다. 또한 피판의 이동이 커 모발선 이 부자연스럽고 어색한 표시가 나기도 한다. 이러한 문제를 해결할 수 있는 절개 방법이 두발선을 따라하는 방식이다 (Fig. 1B). 두발선을 따라 하는 절개는 이마가 긴 환자의 경우 시술 후 이마를 짧게 할 수 있다는 장점이 있고, ${ }^{1)}$ 내시경을 이 용한 이마거상술과 비교해도 두발선을 후방으로 전위시키지 않는다. ${ }^{2)}$ 관상 이마거상술에서는 먼저 이마의 높이나 눈썹의 위치를 어느 정도 올릴 것인지를 평가해야 하며 두 절개방법 모두 측두부에서는 helical-facial sulcus 위에서 시작하여 두발선 또는 관상 부위와 만나게 해야 한다. 측두부에서는 너 무 깊게 절개를 넣어 측두근을 손상시키지 않도록 조심해야 한다. 절개를 시행한 뒤 모상건막하 또는 골막하로 박리를 시작하여 미간 주름을 형성하는 corrugator supercilii근을 제거한다. 시술 전 환자의 미간의 주름을 표시한 뒤 들어올린 전두피판에서 corrugator superciliii근을 분리하고 다시 corrugator supercilii근과 depressor supercilii근을 분리한 뒤 이들을 각각 근치적 절제술을 시행한다. 또한 미간의 가로 주 름을 만들고 눈썹의 내측을 낮추는 procerus 근육 절개를 시 행한다. 이마 중앙에서 전두근 절제를 가위를 이용하여 이마 의 중앙부위에서 가로 형태의 띠 모양으로 $1 \mathrm{~cm}$ 정도를 제거 한다. 이때 근육을 일부만 절제하여 전두부위가 함몰되거나 피부가 울퉁불퉁해지는 것을 예방한다. 근육을 제거한 뒤 음 압 배액을 삽입하고 이마의 거상과 함께 눈썹의 형태가 가장 이상적인 높이로 전두피판을 재배치한 뒤 남는 피판의 일부 를 제거하고 피판을 고정한 뒤 봉합을 시행한다.

\section{내시경을 이용한 이마거상술}

내시경을 이용한 이마거상술의 장점은 탈모, 감각이상, 안면 신경손상의 발생가능성이 적고 수술부위 상처가 개방형 관 상 이마거상술에 비해 작다는 점이다. 먼저 상안와신경과 활 차신경이 나오는 곳을 표시한 뒤 이마의 중앙에서 $1.7 \mathrm{~cm}, 2.7$ $\mathrm{cm}$ 떨어진 지점에 절개를 위한 표시를 한다. 두발의 뒤쪽 1.5 $\mathrm{cm}$ 떨어진 부위에 중앙과 중간 절개선은 $1.5 \mathrm{~cm}$ 길이로 표시 를 하고 측두부위는 $2 \mathrm{~cm}$ 정도로 절개선을 만든다(Fig. 1C). 중앙부위와 중간부위는 절개를 시행하고 골막하면으로 박리 를 하고 측두부위는 천측두근막과 심측두근막 사이로 박리 를 하고 temporal crest 지점에 이르면 골막하면으로 박리를 시작한다. 중앙 및 중간 절개부위를 통한 박리도 골막하면으 로 시행하며 상안와공 $1 \mathrm{~cm}$ 위쪽까지만 박리한다. 이후 내시 경을 삽입하고 안와외측연 부위 박리와 함께 상안와연부위 박리를 한다. Endoscopic grasping forcep을 이용하여 corrugator supercilii근, depressor supercilii근, procerus근 절 제를 시행한다. 주변조직의 충분한 박리가 되면 원하는 위치 에 이마를 위치시킬 수 있도록 두개골에 드릴을 이용하여 작 은 구멍을 만들고 3-0 polydioxanone 봉합사를 이용하여 고정을 시행한다. 드릴을 이용하여 고정시 두개골의 두께를 아는 것이 중요한데, 두개골의 두께는 $1.1 \sim 13.6 \mathrm{~mm}$ 이고 평균 $6.1 \mathrm{~mm}$ 이며, 관상봉합선 2 4 cm 뒤가 가장 두껍고 관상봉 합선 $1 \mathrm{~cm}$ 앞이 가장 얇다. 정중앙에서 외측으로 갈수록 얇 아져 중앙에서 $7 \mathrm{~cm}$ 외측의 두께는 평균 $5 \mathrm{~mm}$ 이다. 공홍합사 를 이용하여 피판을 두개에 고정하는 방법 이외에 티타늄 나 사, Kirschner 철사, Endotine ${ }^{\circledR}$ 등을 이용하여 전두피판을 두개골에 고정하기도 한다. ${ }^{4)}$ Fibrin 글루를 이용하여 전두피 판을 고정하는 것은 두개골에 구멍을 뚫고 고정하는 방법이 
나 Mitek 티타늄을 이용하여 영구적으로 고정하는 방법에 비 해 재발의 가능성이 높다. ${ }^{5)}$ 피판을 고정 후 음압배액을 삽입한 뒤 두피 절개를 봉합한다.

\section{합병증}

개방형 관상 이마거상술의 합병증으로는 출혈, 혈종, 신경 손상, 종창과 피부괴사, 탈모, 눈썹의 비대칭, 절개 부위 반흔 등이 있고, 내시경 이마거상술의 합병증으로는 안면신경의 측두가지 손상으로 인한 안면마비, 절개부위의 탈모, 상활차 신경의 심부가지 손상으로 인한 감각 이상이 있다.

\section{안면거상술}

1901년 독일의 Hollander가 안면거상술에 대한 개념을 가 지고 있다고 인용된 것이 처음이며 1902년 미국의 Cantrell과 1903년 프랑스의 Cabanes가 주름제거술을 최초로 시행한 것으로 알려져 있다. 이후 독일의 Lexer 등이 의해 현재 개념 의 안면거상술을 시행하며 발전시켰다.

\section{SMAS 해부학}

Superficial musculoaponeurotic system(SMAS)은 parotid fascia와 그 위 지방조직 위에 위치하며 SMAS 위층의 피하지 방과 피부와는 섬유성 유착으로 연결되어 있다. Buccal fascia 는 위로는 temporoparietal fascia와 연결되어 있고 아래로는 platysma와 연결되어 있다.

\section{시행방법}

측두부위 모발선 안쪽에 절개를 하는 방법은 이개상방 7.5 $\mathrm{cm}$, 모발선 후방 $5 \mathrm{~cm}$ 정도에서 절개를 시작한다. 이 방법은 모발선을 후방이동 시킬 수 있기 때문에 재수술이나 모발선 이 후방으로 편위된 사람에게서는 사용하지 않는 것이 좋다. 모발선을 후방이동 시키지 않기 위해서는 측두부에서 모발 선을 따라 절개하는 방법이 있다. 칼은 $30^{\circ}$ 각도로 피부에 기 울여서 절개가 진피에 비스듬하게 되게 하고 모발의 줄기와 는 수직이 되게 한다. 귓바퀴를 따라 내려오다 이주에서 이 주 안쪽 또는 이주 앞쪽에 절개선을 연장한다. 이후 귓볼 밑 을 지나서 귀의 부착선을 따라 진행하다 inferior crus 정도 높 이에서 다시 후방 mastoid 방향으로 향한다(Fig. 2A). 피판 은 칼을 이용하여 박리하는데 하악각과 협골궁 부위를 미리 표시해야하며, 박리시에는 SMAS 위에 약간의 지방을 붙이 고 박리를 하는 것이 나중에 SMAS가 얇아 찢어지는 것을 예 방할 수 있다. 측두부위에서는 귀와 lateral canthus 중간부 위까지는 칼 등으로 박리를 하고 이후 검지를 이용하여 orbicularis oculi와 temporalis fascia를 분리한다. 귀의 앞쪽에 서는 하악각과 malar eminence를 연결한 선까지 박리하는데 이는 zygomaticus major muscle 부위에 해당한다. 얼굴 아래 쪽에서는 박리를 labiomandibular fold 부위까지 박리한다. Mastoid 부위 박리는 아래쪽으로 내려오는데 sternocleidomastoid muscle 전체 높이의 반 정도까지 박리하고 내려온 다. SMAS를 거상하는데 이하선의 앞쪽 경계까지는 진행하 지 않는 것이 좋다. 아래쪽으로 박리를 진행하여 mandibular
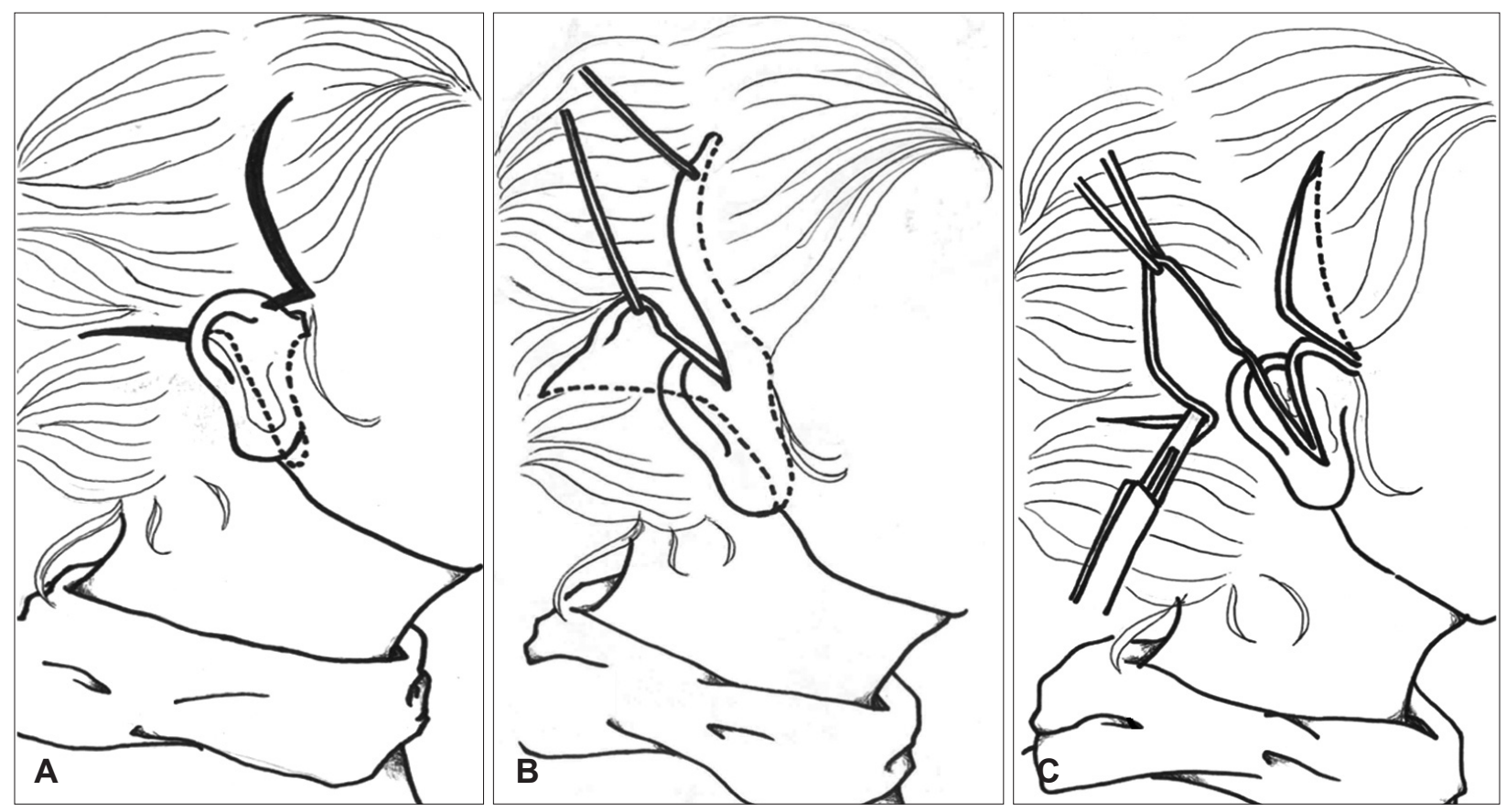

Fig. 2. An incision is made for a facelift (A). After dissection, the redundant skin is retracted (B) and resected (C). 
ligament를 끊어서 SMAS 이동을 쉽게 한다. 이후 SMAS를 후상방으로 당긴 뒤(Fig. 2B) 남는 부분을 절제하고 봉합한 뒤 피부를 당겨 남는 피부를 절제하고 봉합한다(Fig. 2C).

최근에는 short scar facelift with lateral SMAS 절제방법의 안면거상술 및 최소 침습방법으로 minimal access cranial suspension(MACS) lift 등이 시행되고 있다. MACS lift는 SMAS에 jowl, marionette line과 목쪽을 purse string suture 를 통해 당겨 협골궁 위의 심측두근막에 고정 봉합하고 남 는 피부를 자르고 봉합한다.

\section{합병증}

수술 후 혈종, 신경손상, 장액종 등이 합병증으로 올 수 있 으며, 신경손상의 경우, 대이개신경손상이 $2.6 \%$ 까지 보고되 며, ${ }^{6}$ 다른 감각신경에 비해 손상으로 인한 장애가 자주, 그리 고 더 심하게 나타나는데 감각이상, 통증성 결절, 추위에 불편 감 등의 형태로도 나타난다. 압박드레싱과 음압 배액을 사용 하면 혈종, 장액종의 발생을 감소시킬 수 있고 tissue sealant 를 사용하면 혈종의 발생률을 낮출수 있다. ${ }^{7)}$

\section{Blepharoplasty}

쌍꺼풀은 거근건막이 상안검 피부와 안륜근에도 분포하여 눈을 뜰 때 그 부위가 위로 당겨지며 생기는 상안검 주름이 다. 동양인에서 쌍꺼풀이 없는 이유는 거근건막이 검판 앞쪽 의 안륜근에 분포하지 않는다는 점과 거근건막 앞의 지방이 아래쪽까지 내려와 있기 때문이다. ${ }^{8)}$
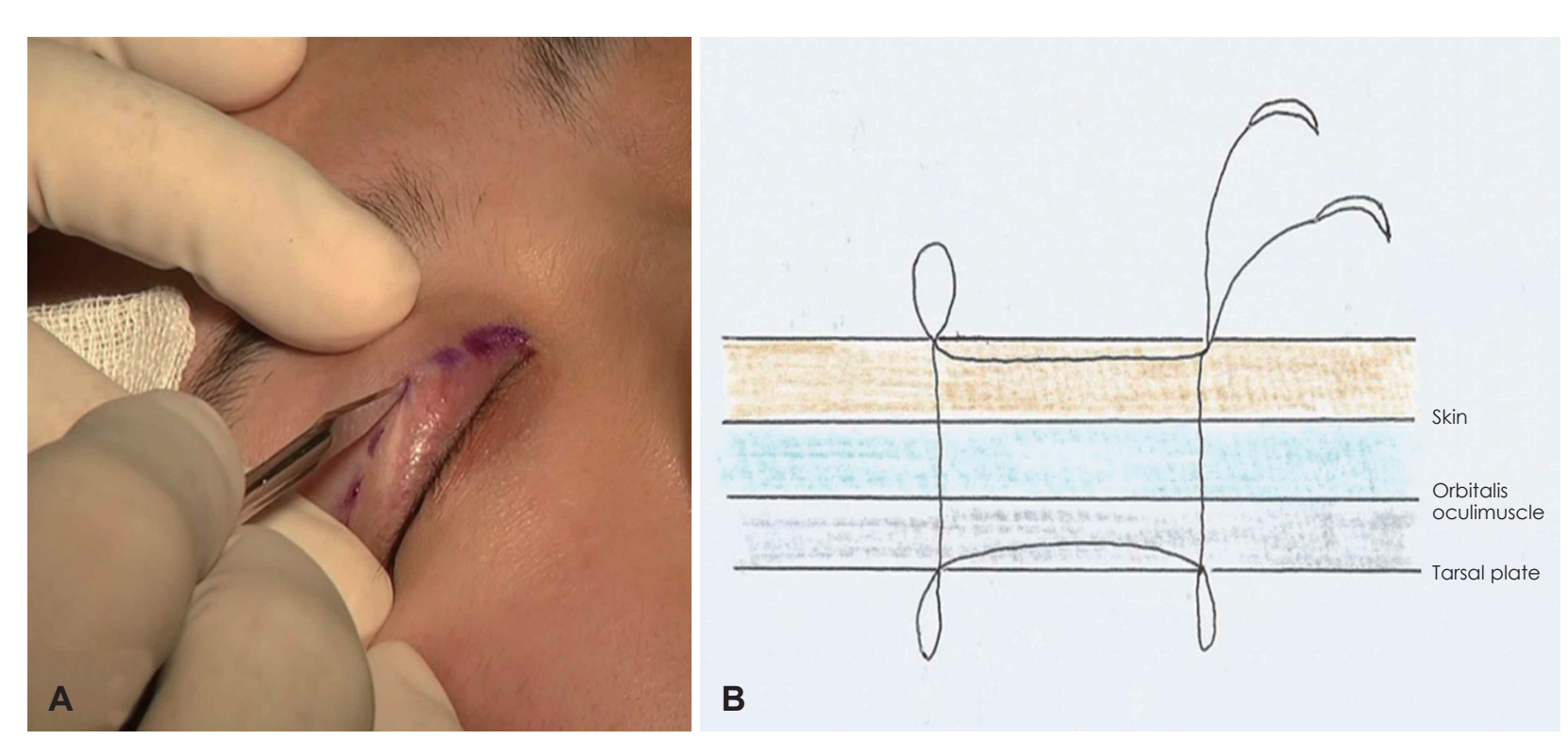

Fig. 3. Small incisions (A) and schematic design (B) for an upper blepharoplasty suturing technique.

\section{Upper blepharoplasty}

\section{절개법}

동양인에서는 속눈썹에서 대개 6 7 mm 정도의 크기로 쌍꺼풀을 만드는 것이 자연스럽다. 더 크게 원하는 경우는 $10 \mathrm{~mm}$ 까지 도안을 한다. 제거할 피부는 겸자로 미리 측정을 한 뒤 도안하고 제거하는데 3 10 $\mathrm{mm}$ 정도까지 제거할 수 있 고 피부만을 제거하거나 또는 안륜근을 포함하여 제거한다. 안와격막을 절제하면 격막 안쪽의 지방이 나오고 지방을 제 거하면 술 후 눈이 소복해 보이는 것을 예방할 수 있다. 그러 나 과도하게 지방을 제거하면 공막이 보이거나 눈이 꺼져 보 이게 될 수 있으므로 주의한다. 검판 위의 안륜근을 일부 제 거하면 술 후 쌍꺼풀이 두툼해 보이는 것을 예방할 수 있다. 아래 절개선은 안검판이나 거근건막에 비흡수성 봉합사를 이용하여 고정하고 피부를 봉합한다.

\section{매몰법}

이 방법은 안검을 개방하지 않고 봉합사를 이용하여 진피와 검판 또는 진피와 거근건막을 연결하여 쌍꺼풀을 만드는 방 법이다. 먼저 결막에 국소 마취액으로 마취를 시행하고 피부 쪽에도 침윤마취를 시행한다. 피부쪽에 쌍꺼풀을 만들고자 하는 높이를 caliper를 이용하여 측정한 뒤 표시를 한다. 눈 꺼풀을 뒤집어 결막쪽의 검판에도 같은 높이로 표시를 한다. 11번 blade를 이용하여 피부쪽과 결막쪽 표시점에 작은 절개 창을 만든 뒤(Fig. 3A), 7-0 double arm nylon으로 피부쪽으 로 들어가 결막쪽으로 나오고 결막쪽에서 검판 또는 거근건 막을 어느 정도 포함한 뒤 다시 피부쪽으로 나온 뒤 처음에 
들어간 피부쪽으로 나와 매듭을 시행하는 방법으로 쌍꺼풀 을 만든다(Fig. $3 \mathrm{~B})$. 작은 절개창을 통해서 지방 제거도 가능 하고, 시술자에 따라 1 5개 정도로 봉합을 만들며, 대개 나이 가 20대 초반의 어린 환자에게 적합하다.

\section{합병증}

안검하수, 안검함몰, 비대칭, 봉합사 노출, 삼겹 쌍꺼풀, 비 후성 반흔, inclusion cyst, 쌍꺼풀 풀림, 안구건조 등이 있다. 안검하수의 경우 수술 전 안검하수를 인지하지 못해 수술 후 더 심해지는 경우가 많으며, 안검함몰의 경우 지방을 너무 제 거하여 발생할 수 있으므로 이를 주의한다. 삼겹 쌍꺼풀은 술 전 과다한 피부를 적게 절제한 경우나 거근건막에 고정이 제 대로 되지 않을 때 발생할 수 있다. 비후성 반흔 예방은 수술 후 스테로이드 연고를 절개부위 도포하고 봉합부위 긴장이 생기지 않도록 주의하며, inclusion cyst의 경우는 수술로 제 거해야 한다. 안구건조증의 경우 수술 전에 안구건조증 유무 를 확인해야 하며 눈성형을 받고자 하는 환자의 약 $15 \%$ 까지 안구건조증이 있다고 보고된다.")

\section{Lower blepharoplasty}

나이가 들어감에 따라 하안와격막이 늘어지고 지방이 돌 출되어 보인다. 하안검성형술은 하안검의 피부만 올려 피부 만 제거하는 피판법과 안륜근과 피부를 포함한 근피판법, 그 리고 결막을 통해 지방을 제거하고 남는 피부를 제거하는 경 결막 접근법, 지방 재배치법 등이 있다.

\section{시행방법}

피판법과 근피판법의 경우 먼저 하안검연에서 $2 \sim 3 \mathrm{~mm}$ 아 래에 절개를 하고 안륜근과 안와격막 사이 아래쪽으로 박리 를 한다. 지방이 많아 눈 아래가 돌출된 경우는 안와격막을 열고 지방을 제거하는데 지방은 외측, 중앙, 내측 지방으로 나뉘며 중앙지방과 내측지방 사이에는 하사근이 위치하므로 이 부위 지방 제거 시 하사근의 손상에 주의한다. 이때 눈을 누르면 지방이 돌출되어 나오므로 하사근과 지방을 감별할 수 있다. 지방을 제거하고 근피판의 경우 피부와 안륜근을 박리한 뒤 안륜근을 외측 안와연의 골막에 봉합을 하고 남 는 피부를 제거한 뒤 봉합한다. 피판법의 경우는 지방을 제
거하고 남는 피부를 제거하고 봉합한다. 경결막 접근법은 (Fig. 4) 결막의 가장 불룩한 부분에 절개를 하고 박리를 아 래쪽 안와연 방향으로 시행하는데 면봉을 이용하면 좀 더 쉽게 박리가 된다. 안와격막과 안륜근 사이로 박리를 한 뒤 격막에 절개를 시행하면 지방이 나오고 이를 제거한다. 제거 후 출혈은 철저하게 지혈한다. 지방을 제거한 뒤 남는 피부를 forcep으로 잡아 제거하는 pinch method를 이용하여 제거 한다. 남는 피부 제거 후 nylon 7-0으로 피부 봉합을 하며 결막의 경우는 1 2군데 봉합을 하거나 봉합을 시행하지 않 아도 된다. Tear trough deformity가 있으면 내측지방이나 중 앙지방을 제거하는 것보다 지방을 재배치하는 것이 더 효과 적일 때도 있다. Tear trough deformity를 넘어서 아래쪽까지 박리를 하고 periosteum 위로 지방재배치를 위한 pocket을 만든다. 내측과 중앙의 지방이 불거져 나오면 아래쪽에 절개 를 해서 지방이 release 되게 한 뒤 fat pedicle을 만들어 tear trough 아래쪽으로 fat을 이동시켜 tear trough 아래쪽으로 지 방을 재배치하고 봉합사를 이용하여 고정한다.

\section{합병증}

하안검 성형술 후 혈종, 흥터, 안검외반, 안구건조증 등이 올 수 있다. 안검외반의 경우 초기에 마사지 등으로 호전될 수 있고, 지속시에는 수술적 치료가 필요하므로 안검외반을 예 방할 수 있도록 피부 절제를 보존적으로 시행한다. 수술 후 생 긴 안구건조증의 경우, 일시적인 경우가 많으며 약 3 개월 정도 후에는 대부분 호전된다. ${ }^{10)}$

\section{안면지방주입술}

노화가 진행되면서 콜라겐, 피하지방의 감소 등으로 안면 부 함몰부위가 생기게 된다. 이러한 함몰부위는 자가지방 주 입술을 통해 좋은 효과를 보일 수 있다. 또한 지방주입술은 그 술기가 간단하고 국소 마취하에서도 가능하나, 고혈압, 당 뇨 등 전신질환이 있거나 노인 환자에서는 장시간의 지방채 취 및 과도한 주입이 문제를 일으킬 수 있으므로 주의하여 시행한다.
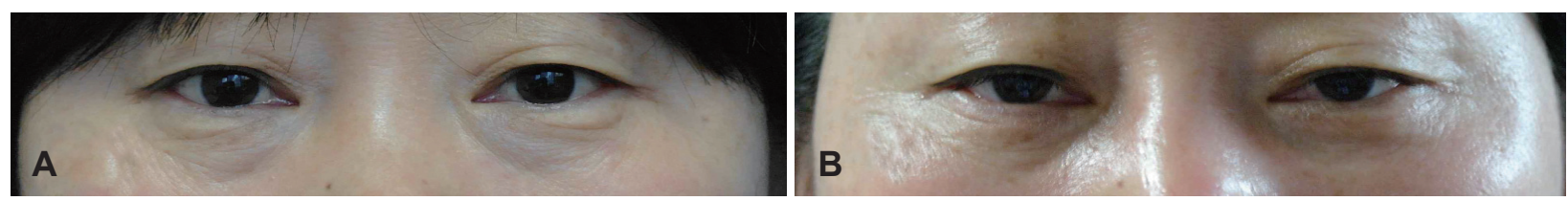

Fig. 4. Lower blepharoplasty using a transconjunctival approach with a pinch technique. Preoperative image (A). Postoperative image (B). 


\section{지방채취부위}

지방 이식 후 생착된 지방은 이식부위의 성질보다는 채취부 위의 성질을 가지므로 체중변화에 잘 반응하지 않는 부위인 허벅지, 둔부, 복부가 좋은 지방 공여부위이다.

\section{시술방법}

지방을 채취할 때는 전신마취 또는 경막외 마취하에, 지방 주입시에는 수면 마취 또는 부분마취하에 시행할 수 있다. 채취부위의 마취는 투메슨트 용액(생리식염수 1 L+lidocaine $1000 \mathrm{mg}+1: 1000$ epinephrine $1 \mathrm{mg}$ )을 투메슨트 주입용 캐 뉼라를 이용하여 채취하고자 하는 지방의 2 4배 정도를 주입 하는데, 투메슨트 용액은 지방을 쉽게 채취할 수 있도록 도 와주며, 마취효과와 함께 출혈 및 지방 색전증 예방에 도움 을 준다. 투메슨트 용액 주입 15분 뒤 지방 흡입용 캐뉼라를 이용하여 지방을 흡입한다. 분리된 지방은 $3000 \mathrm{rpm}$ 에서 약 5 분간 원심분리를 시행한 후 $1 \mathrm{cc}$ 시린지로 옮겨담아 주입부 위에 $18 \mathrm{G}$ 바늘로 작게 구멍을 낸 뒤 끝이 둥근 캐뉼라로 여 러층에 나누어 주입을 하는데 한 번 주입시 $0.1 ~ 0.2 \mathrm{cc}$ 정도를 주입한다. 주입 시 캐뉼라를 살짝 들어올려 피부와의 마찰을 줄여야 피부 마찰로 인한 변색을 예방할 수 있다. 이마의 경 우 지방을 대략 20 30 cc를 주입하는데 미간부위는 혈관이 풍부하므로 지방 색전증이 생기지 않도록 주의한다. 관자놀 이부위는 절개선은 모발선 가까이에 만들고 지방을 주입하 는데 주입위치는 temporpaietal fascia 위의 피하지방층에 주 입하고 주입량은 2 3 cc 정도이다. 볼살 부위는 노화를 겪으 면서 malar fat pad의 소실 등으로 함몰되는 부위로 디자인을 할 때 역삼각형으로 도안하고 입술의 끝에서 $1.5 \mathrm{~cm}$ 정도 떨 어진 곳을 통해 캐뉼라를 이용하여 여러층에 걸쳐 주입을 하 는데 깊은 층부터 낮은 층 순으로, 캐뉼라를 빼면서 fanning technique으로 주입한다. Nasolabial fold 외측에 주입을 많 이 하면 nasolabial fold가 더 깊어 보이므로 주의한다. Nasojugal groove 부위도 groove 위쪽이나 아래쪽으로 주입을
많이 하면 groove가 더 도드라지는 부작용을 초래할 수 있다. Sunken eye인 경우 눈을 위로 보게 한 상태에서 함몰된 경 계를 결정하고, 상안검의 피부는 얇아 주입 후 울퉁불퉁하게 만져질 수 있으므로 안륜근 가까이 피하 깊은 층에 소량을 골고루 주입해야 한다. 입술 부위 지방주입은 윗입술과 아랫 입술이 만나는 부위에서 약간 떨어져 $18 \mathrm{G}$ 바늘로 절개를 한 뒤 캐뉼라가 들어갈 수 있도록 터널닝을 한 뒤 입술 피부부 위뿐만 아니라 점막부위 전체적으로 지방을 주입한다. 옆모 습이 윗입술, 아랫입술, 턱이 일직선이 되도록 주입하고 아랫 입술에 전체적으로 지방을 주입하면 소시지 모양이 나오므 로 구강각쪽의 주입은 너무 과도하지 않도록 주의한다. 주입 된 지방의 생착률을 높이는 방법으로는 좋은 공여부 선택과 함께 채취시 압력을 높이지 않아야 하며, 주입시에는 부채살 모양으로 여러층으로 주입하는 것이 좋다. 지방 채취시에도 캐뉼라 직경이 클수록 좋은데 $2 \mathrm{~mm}$ 보다는 $4 \mathrm{~mm}$ 를 사용하 면 2배 정도의 더 높은 생존율을 보이고, $4 \mathrm{~mm}$ 보다 $6 \mathrm{~mm}$ 를 사용하면 생존율이 더 좋다.11) 이외에 지방 주입시 배양액, ${ }^{22}$ 인슐린, 섬유모세포 성장인자 ${ }^{13)}$ 등을 함께 투여하면 생착률 이 증가한다.

\section{합병증}

멍과 상처, 염증(Fig. 5A), 피부탈색(Fig. 5B), 혈종, 부종, 지 속된 홍반, 통증, 압통 등이 있다. 심각한 합병증으로는 망막 동맥의 폐쇄에 따른 일측시력상실 ${ }^{14)}$ 및 미간부위 주입 후 중 대한 중추 신경계의 손상이 보고되고 있다. ${ }^{15)}$

\section{턱끝 성형술(Genioplasty) 및 이식물을 이용한 턱끝 확대술}

턱끝 성형술은 하악 중 턱끝이 짧게 보이거나 비대칭인 경 우 턱뼈를 잘라 상하, 좌우, 전후로 이동시키는 방법으로 정 면에서 안면은 3 분할법으로 이마, 코의 길이, 턱까지의 거리
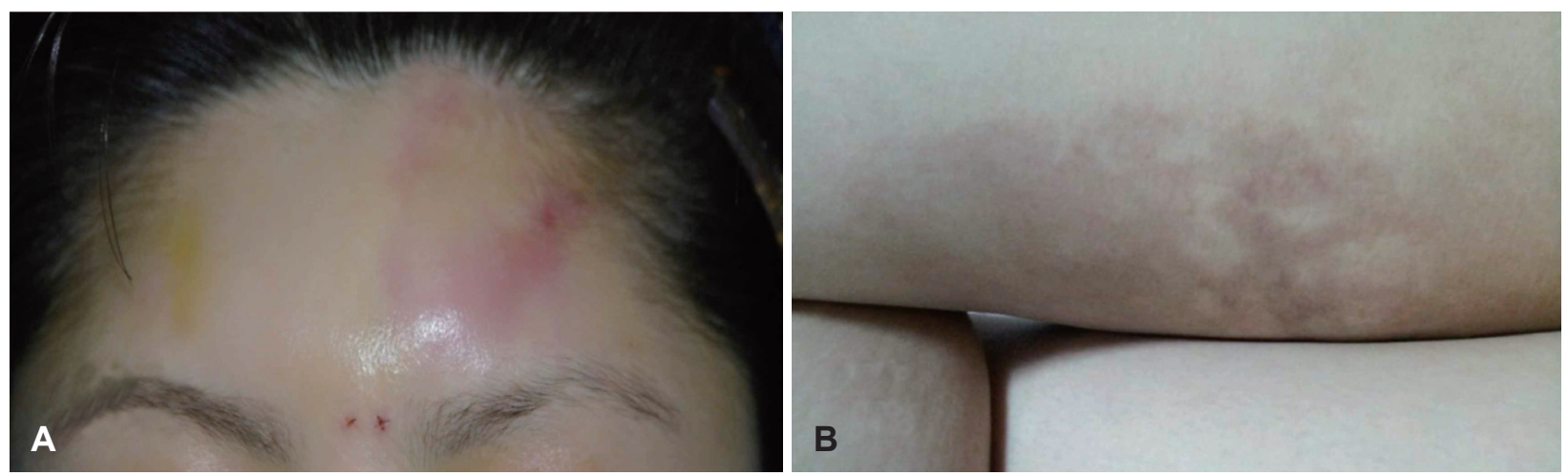

Fig. 5. Forehead inflammation after autologous fat injection $(A)$ and skin discoloration of the medial thigh after fat aspiration (B). 


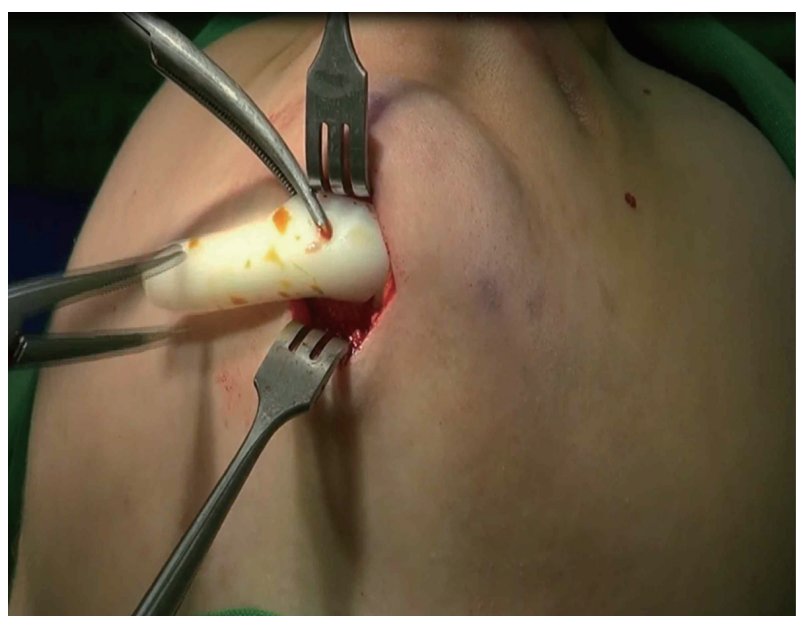

Fig. 6. Alloplastic chin augmentation. An implant is being inserted through the skin incision behind the submental crease.

가 3 등분이 되는 것이 균형적인 모습이며, 옆 모습에서는 코 끝, 위 아래 입술, 턱 끝선이 일직선 상에 놓여야 자연스럽다. 이식물을 이용한 턱끝 확대술은 턱이 짧거나 후퇴된 경우 입안 점막이나 턱아래 피부를 절개하고 이식물을 삽입하여 미용 적 개선을 얻을 수 있다.

\section{턱끝 성형술}

하악구강내 점막에 양측으로 $3 \sim 4 \mathrm{~cm}$ 크기의 절개를 가한 다. 골막하면을 따라 턱끝까지 박리를 시행하고 이후 양측 옆으로 박리를 하여 mental nerve를 확인해야 하는데 mental foramen은 제2소구치 아래에 위치한다. Reciprocating saw 를 이용하여 하악절개시 mental foramen보다 최소 $6 \mathrm{~mm}$ 아 래에 절골선이 위치하게 하는데 이는 mental nerve가 mental foramen보다 아래로 지나 나오기 때문이다. Reciprocating saw로 하악 전체를 자르면 하악 안쪽 연조직이 손상받을 수 있으므로 하악골 내측 일부를 남긴 뒤 절골도를 이용하여 절골시킨다. 턱이 긴 경우는 일부 뼈를 제거하고, 비대칭인 경우는 절골을 시행 후 뼈를 이동시킨 뒤 미니플레이트 또는 철사를 이용하여 고정한다. 하악 높이를 축소하거나 비대칭 의 하악교정시 잘라낸 뼈를 이동시킴으로써 발생하는 굴곡 부위는 튀어나온 뼈를 제거하여 매끄럽게 만들어준다. 잘라 낸 뼈를 새로운 위치에 고정시 뼈 사이에 틈이 발생하면 인조 뼈 등을 이식하여 틈을 메워준다. 이후 충분한 지혈을 하고 점막을 봉합한 뒤 탄성붕대를 이용하여 압박을 시행한다.

\section{이식물을 이용한 턱끝확대술}

국소마취로 양측 mental nerve를 차단하고 턱 아래 절개부 위에 국소마취를 한다. 이식물의 정중앙부위에 작은 홈을 만 들어 표시를 하고 턱의 정중앙에도 표시를 하여 이식물 삽입
시 이식물이 턱의 정중앙에 위치하도록 한다. 입안 점막에 절 개를 넣는 방법과 피부를 절개하는 방법이 있다. 입안 점막 을 통한 방법은 $5 \mathrm{~mm}$ 정도의 점막을 남겨두고 길이는 $3 \mathrm{~cm}$ 정도로 절개를 시행하는데 이식물의 길이보다 길지 않도록 한 다. 피부를 통한 방법은 submental crease 약간 뒤쪽에 약 3 $\mathrm{cm}$ 정도 절개를 가한다. Periosteal elevator를 이용하여 골 막을 거상시키는데 양측 견치 외측부위는 골막하로, 양측 견 치 사이는 골막위로 박리하여 이식물을 박리한 면으로 삽입 한다(Fig. 6). 박리한 부위가 너무 넓으면 이식물이 원하는 위 치에서 이동될 수 있고 너무 작으면 이식물 삽입이 어려우므 로 적절한 크기로 만드는 것이 중요하다. 또한 이식물은 하악 의 아래 연보다 위에 위치하게 하여 ptotic chin을 예방한다. 이후 이식물을 주변 연조직과 함께 1 2부위 봉합하여 이동하 지 않도록 한 뒤 근육과 피부를 봉합한다.

\section{합병증}

Mental nerve 손상, 미용적 문제(과교정, 미교정, 비대칭), 감 염 등이 있다. Mental nerve 손상시 손상된 mental nerve의 말 단부위를 이어주어야 하며, 적절한 항생제의 사용에도 지속되 는 감염의 경우 이식물의 제거가 필요하다. 이외 골의 흡수, 감 염, 이식물의 이탈 및 위치 이동, capsular contraction, lowerlip retraction, chin ptosis, delayed mental nerve neuralgia 등하이 있다.

\section{목 성형술}

노화가 진행되면서 목의 변화는 cervicomental angle이 점 차 둔각이 되고 platysmal band와 피부이완이 눈에 띄게 증가 한다. 정면에서는 platysmal band, 측면에서는 cervicomental angle의 평가가 용이하다.

\section{시술방법}

침윤마취를 시행 후 submental crease $0.5 \mathrm{~cm}$ 뒤쪽, 평행 하게 $3 \sim 5 \mathrm{~cm}$ 가량의 절개를 가하고 피판은 지방을 약 $5 \mathrm{~mm}$ 정도는 남긴 채 아래로 갑상연골부위까지 진행한다. Mandibular retaining ligament를 잘라주고 피부를 재배치하는 것 이 술 후 mandible 윤곽을 좀 더 잘 표현할 수 있다. Platys$\mathrm{ma}$ 앞에 있는 피하지방은 직접 가위나 bovie로 제거하거나 suction을 이용하여 제거하고, platysma 안쪽에 있는 지방은 가위나 bovie로 제거한다. Digastric muscle의 anterior belly 가 비후한 경우 전체 또는 일부를 제거할 수 있고 악하선이 커서 미용적 문제를 유발하는 경우 일부를 절제한다. 술 후 배 액관을 삽입하고 압박 드레싱을 하며, 환자가 목을 구부리면 
정맥 울혈로 인해 부종이 오래갈 수 있으므로 목을 약간 신전 시킨 자세가 좋다.

\section{합병증}

혈종과 안면신경의 marginal mandibular branch 손상, 장 액종 등이 있다.

\section{보 톡 스}

보툴리눔 톡신은 20세기 중반부터 의학적 목적으로 사용 되어져 왔으며, 8 개의 serotype이 있고, 이 중 $\mathrm{A}$ 형이 인간에서 가장 강력한 효과를 나타낸다. 보툴리눔 톡신은 신경근 접합 부에서 신경전달 물질인 아세틸콜린의 분비를 저해함으로써 근수축을 방해한다. 따라서 잦은 근 수축으로 인한 주름의 개선에 효과적이다. 시술자에 따라 다르나 보통 $100 \mathrm{U}$ 보톡 스 ${ }^{\circledR}$ 에 $2.5 \mathrm{cc}$ 생리식염수를 섞어 $0.1 \mathrm{cc}$ 당 $4 \mathrm{U}$ 이 포함되게 하 여 사용하는 것이 편하다. 주사 후 2 4일째 근육의 약화가 나 타나고 7 10일째 근육의 탈신경화가 최대치에 이른다.

\section{이 마}

이마 주름의 경우, 주름이 깊지 않고 피부가 늘어져 생기지 않은 경우에 한해 보톡스의 치료 대상이 되며 전두근에 보톡 스 ${ }^{\circledR}$ 2 3 U을 약 $1.5 \mathrm{~cm}$ 간격으로 5 6군데 주사한다(Fig.
7A). 주사시 눈썹으로부터 3 4 cm 정도 위에 주사하여 brow ptosis를 예방한다. 전두근은 눈썹을 위로 올리는 기능이 주 된 역할을 하므로 윗 눈꺼풀이 처진 환자는 전두근에 보톡 스 시술을 할 경우 눈꺼풀이 더 처져서 시야를 가릴 수 있으 므로 주의한다.

\section{양미간의 주름}

Corrugator supercilli 근, depressor supercilli 근, procerus 근이 양미간의 주름과 콧등의 주름을 만든다. Procerus 근 은 콧등의 transverse한 주름을 만들고 이를 없애기 위해서 는 보톡스 ${ }^{\circledR} 5 \sim 10 \mathrm{U}$ 을 procerus 근에 주사하고, corrugator 근 을 따라 2 3군데 3 5 U을 주사한다.

\section{외측 눈가주름(Crow's feet)}

외측 눈가주름의 경우 lateral orbital rim에서 $1.5 \mathrm{~cm}$ 가 량 떨어진 곳에 가장 눈주름이 많은 곳에 $2 \mathrm{U}$ 을 주사하고 처음 주사한 곳에서 $1 \sim 1.5 \mathrm{~cm}$ 위쪽과 아래로 $2 \mathrm{U}$ 을 추가로 주사한다. 눈을 더 크게 하기 위해서는 mid-pupillary line 아 래 orbicularis oculi muscle에 2 4 U을 추가로 주사한다.

\section{입가주름}

미세한 입가주름은 vermilion border $2 \mathrm{~mm}$ 위에 $0.5 \mathrm{U}$ 을 윗입술 부위 5 6군데, 아랫입술 부위는 4군데 정도 주사한
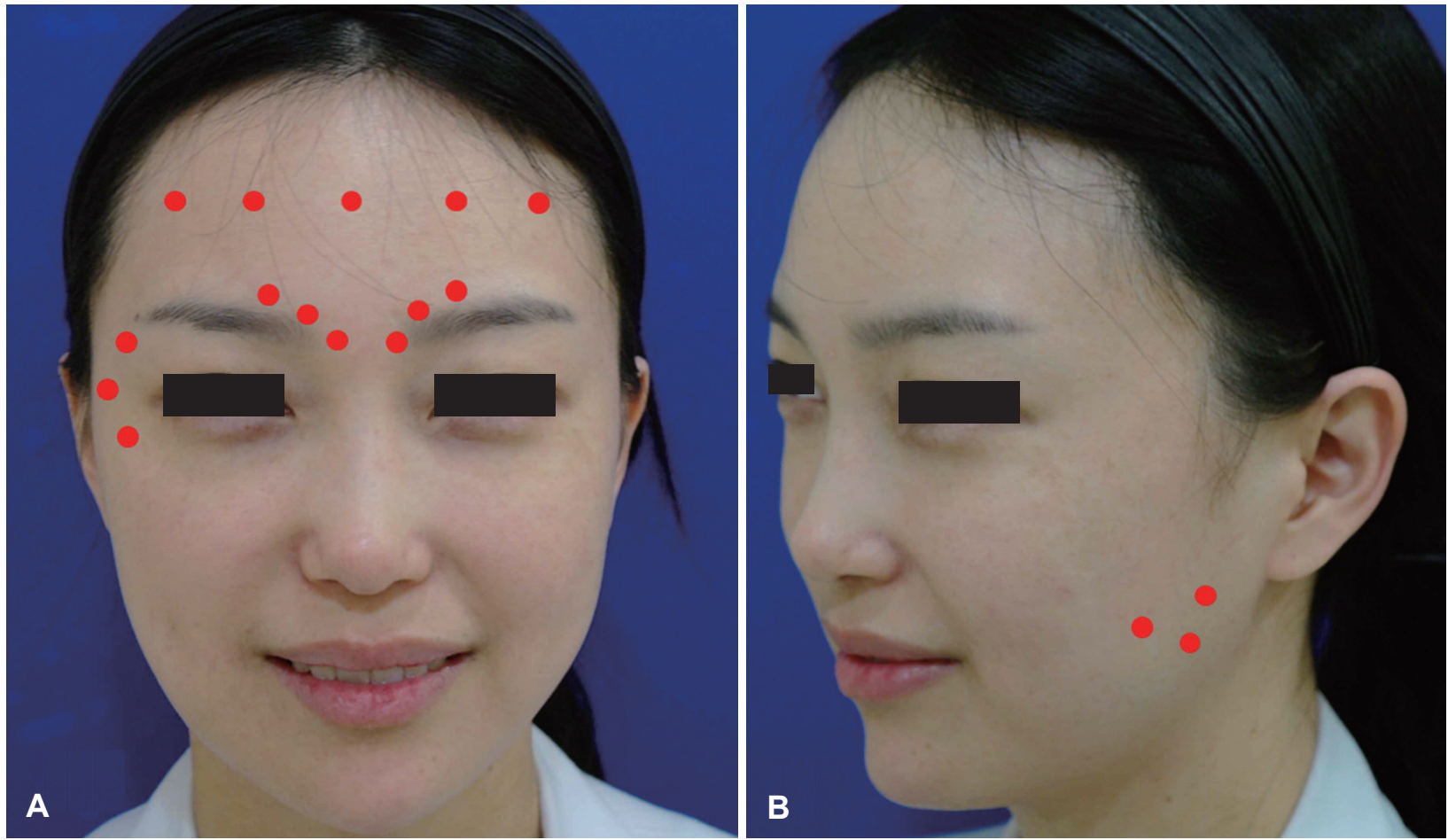

Fig. 7. Botulium toxin injection sites for treating forehead wrinkles, crow's feet (A), and massetor hypertrophy (B). 
다. 처진 구각부위를 올리기 위해서는 구각부위 아래, 하악연

의 $1 \mathrm{~cm}$ 위쪽에 $2 \mathrm{U}$ 을 주사한다.

\section{사각턱}

사각턱 치료에는 환자의 정면과 측면에서 이를 꽉 다물게 하 여 masseter hypertrophy를 확인하고 하악의 하연에서 1.5 $\mathrm{cm}$ 정도 위에 $8 \mathrm{U}$ 을, 삼각형 모양으로 3 군데에 $0.8 \mathrm{~cm}$ 정도 깊 이로 주사한다(Fig. 7B).

\section{합병증}

멍이나 반상 출혈, 부종, 두통, ${ }^{17)}$ 감각 이상 등이 국소적으 로 나타날 수 있고 멍은 비타민 E나 아스피린 복용시, 그리고 흡연자에서 잘 생긴다. ${ }^{18)}$ 전신부작용으로는 구역, 감기 증상, 피부 발적 등이 나타날 수 있다. 안면에 많은 용량의 보톡스 를 주사시 무표정한 얼굴 즉 마스크 같은 얼굴을 호소하기도 하며 눈썹 처짐, 안구 건조증 ${ }^{19)}$ 을 초래하기도 한다. 사무라이 눈썹, 즉 눈썹의 중앙부위와 내측부위는 내려가고 외측부위 는 올라가는 형태는 눈가 주름 교정시 독소가 orbicularis oculi 근의 기능을 약화시키고 이마 주름 교정시 전두근 내 측부위만 주사시 전두근의 기능이 약화되어 나타날 수 있다. 이러한 경우 전두근 외측부위에 보톡스를 주사하여 교정할 수 있다.

\section{필 러}

나이가 들어감에 따라 피부 및 피하의 볼륨감소가 일어나 고 이는 안면 골격의 흡수 및 피하지방의 감소, 진피가 얇아 지고 hyaluronic acid의 감소에 기인한다. 최근에는 이러한 안면 노인성 변화를 치료하는 한 방법으로 필러가 많이 사용 되어 있다. 특히 팔자주름과 미간, 눈가주름의 개선에 효과 적이며, 보톡스와 함께 사용되기도 한다. 주된 성분에 따라 콜라겐, 하이알루론산, Ca-hydroxylapatite 필러 등이 있다. Ca-hydroxylapatite 필러로는 Radiesse ${ }^{\circledR}$, Poly-L-Lactic acid 성분의 Sculptra ${ }^{\circledR}$, 하이알루론산 성분의 필러로는 Restylene $^{\circledR}$, Cleviel $^{\circledR}$, Juvederm ${ }^{\circledR}$ 등이 있으며 하이알루론산 성분의 필러는 주입 후 문제시 hyaluronidase에 녹여 없애는 것이 가능하다는 장점을 가지고 있다.

\section{시술방법}

먼저 시술 또는 신경 차단술 시행 15 분에서 30 분 전에 국소 마취 연고를 발라둔다. 주입하는 방법으로는 여러 군데 puncture해 주입하는 방법과 한 곳에 puncture를 하고 바늘을 빼 면서 주입하는 방법이 있다. 또 볼 등 넓은 부위는 panning

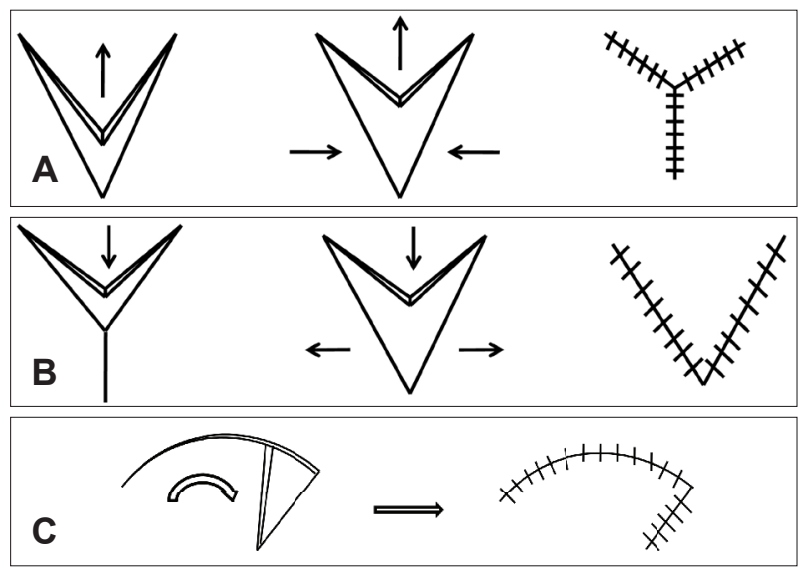

Fig. 8. Local flaps that can be used for correcting facial soft tissue defects. V-Y advancement flap (A), Y-V advancement flap (B), and rotational flap $(C)$.

technique과 cross-hatching technique을 이용하여 주입할 수 있다. 얼굴부위에서 특히 nasolabial fold에 주로 많이 시 술하는데 한 쪽에 1 2 $\mathrm{mL}$ 정도 주입하고 nasolabial fold 시 작부위인 역삼각형 부위를 잘 주입해야 효과가 좋다. 주입하 는 층은 deep dermis로 주입하고 nasolabial fold의 내측 아 래나 외측으로 주입하면 오히려 fold를 깊게 만들 수 있으므 로 주의한다. 또한 너무 과교정을 하면 부자연스러운 모습을 보일 수 있으므로 조금씩 주입하고 시술 후 엄지와 검지를 이 용하여 한 손가락은 입안으로 넣고 다른 한 손가락은 피부쪽 에서 마사지를 하여 주입된 필러가 잘 펴져 도드라져 보이지 않도록 한다. Melolabial fold도 양측에 1 2 mL 정도의 주입 으로 효과를 보이며 이때도 fold의 내측과 외측에 주입시 도 드라져 보이므로 주의한다. 이외 tear trough 부위, 입가의 잔주름, 이마가 꺼진 부위 등에 주입하여 좋은 효과를 보일 수 있다. 시술 후에는 cold pack을 하여 술 후 부종과 멍을 예 방하고 주입된 부위의 움직임을 최소화 하도록 교육한다. 시 술 후 7일 정도는 햇빛에 노출되는 것을 피한다.

\section{합병증}

멍, 부종, 작열감, 불편감, 과교정 등이 있고, 드물지만 세균 감염, 피부괴사, 뇌경색, 실명 등이 보고되었다. ${ }^{20)}$

\section{안면 연조직 손상의 재건}

\section{안면 연조직 손상시 초기치료의 원칙}

오염된 조직은 충분한 생리식염수 세척을 시행하고 죽은 조 직을 깨끗이 제거하고, 타르나 이물이 상처에 묻어있는 경우 초기에 철저히 제거해야 하는데, 표피와 진피의 겉층이 손상 되면 이물과 타르가 진피층에 묻게 된다. 이후 표피와 진피가 
자라며 색소 침착이 영구적으로 남게 된다. 따라서 거즈나 부드러운 솔 등으로 타르나 이물질을 제거하고 식염수 등으 로 충분히 세척한다. ${ }^{21)}$

봉합시 장력이 없도록 봉합해야 상처가 적게 남는다. 이를 위해서는 먼저 피하조직을 봉합하여 dead space를 줄이고 피부 봉합하여 장력이 최소화되게 해야 한다. 양측 상처연은 eversion 시켜 나중에 상처가 함몰되거나 넓어지는 것을 예방 한다. 또한 안면의 열상 및 조직의 결손 재건시 relaxed skin tension line과 평행한 방향으로 절개나 봉합을 시행하면 상 처를 줄일 수 있고, 코의 조직 결손 재건시에는 aesthetic subunit의 경계부위에 절개선이 위치하게 하면 상흔을 줄일 수 있다.

\section{안면 연조직 결손시의 재건 방법}

대부분의 안면부 결손은 국소피판술로 재건이 가능하며 국소피판 방법으로는 advancement 피판법, pivotal 피판법, hinge 피판법이 있다. Advancement 피판법은 피판의 모양 이 직선 또는 $\mathrm{V}$ 형태로 이동하여 결손을 메우는 피판법으로 unipedicle, bipedicle, V-Y, Y-V 피판법이 있다(Fig. 8A and B). Pivotal 피판법은 기준점을 중심으로 피판이 회전 또는 이 동하는 방법으로 여기에는 rotation(Fig. 8C), transposition, interpolated 피판법이 있다. Rotation 피판법은 곡선의 모양 으로 삼각형의 조직결손을 재건하는 데 좋다. Transposition 피판은 피판의 base가 결손부위와 연접하여 이동하며, 회전 할수록 피판의 크기가 줄고 변형이 온다. Interpolated 피판 은 transposition 피판과 비슷하나 그 차이는 피판의 base가 결손부위와 연접하지 않아 stage 수술이 필요하다.

\section{안면 연부 조직 손상에서의 합병증}

\section{감 염}

조직 $1 \mathrm{~g}$ 당 $1 \times 10^{5}$ 이상의 세균이 있으면 감염이 일어나는 데, ${ }^{22)}$ 세균수뿐 아니라 환자의 감염 방어 능력도 감염에 영향 을 미친다.

\section{창상 열개(Wound dehiscence)}

대부분 수술 후 첫 주에 일어나는데 대부분은 tissue failure 에 의해 일어난다.

\section{흥터 증식}

대표적인 예로는 비후성 반흔과 켈로이드가 있는데 이들 은 혈관 과다 및 세포 과다를 특징으로 한다. 차이점으로는 비후성 반흔은 손상 후 바로 발생하며 상처의 경계부위에 제
한되어 나타나고 시간이 지남에 따라 희미해지는 반면 켈로 이드는 손상 후 수개월 후 나타나며 상처 경계를 넘어서도 나 타나고 희미해지는 경우는 매우 드물다. 아직까지 비후성 반흔 과 켈로이드의 원인은 정확하게 밝혀져 있지 않으나 apotosis 과정에 변화가 있는 것이 주된 요인으로 알려져 있다. 또한 두 질환 모두에서 성장인자 특히 transforming growth factor- $\beta$, platelet-derived growth factor, interleukin-1, 그리고 insulin like growth factor-I 등이 증가되어 있다. ${ }^{23)}$ 이러한 성장인자 는 섬유아세포의 증식과 콜라겐 및 세포외기질 생성을 증가 시킨다. 치료가 쉽지 않기 때문에 예방이 더욱 중요하며 상처 부위 국소 corticosteroid 주사는 섬유아세포 증식을 억제하 고 혈관생성 감소 및 콜라겐 합성과 세포외기질 생성을 감소 시킨다.

\section{REFERENCES}

1) Guyuron B, Behmand RA, Green R. Shortening of the long forehead. Plast Reconstr Surg 1999;103(1):218-23.

2) Guyuron B, Gatherwright J, Totonchi A, Ahmadian R, Farajipour N. Cessation of hairline recession following open forehead rejuvenation. Plast Reconstr Surg 2014;133(1):1e-6e.

3) Harirchian $S$, Kuperan $A B$, Shah AR. Safety of cranial fixation in endoscopic brow lifts. Am J Otolaryngol 2013;34(6):690-4.

4) Rohrich RJ, Beran SJ. Evolving fixation methods in endoscopically assisted forehead rejuvenation: controversies and rationale. Plast Reconstr Surg 1997;100(6):1575-82; discussion 1583-4.

5) Jones BM, Grover R. Endoscopic brow lift: a personal review of 538 patients and comparison of fixation techniques. Plast Reconstr Surg 2004;113(4):1242-50; discussion 1251-2.

6) Waterhouse N, Vesely M, Bulstrode NW. Modified lateral SMASectomy. Plast Reconstr Surg 2007;119(3):1021-6; discussion 1027-8.

7) Zoumalan R, Rizk SS. Hematoma rates in drainless deep-plane facelift surgery with and without the use of fibrin glue. Arch Facial Plast Surg 2008;10(2):103-7.

8) Doxanas MT, Anderson RL. Oriental eyelids. An anatomic study. Arch Ophthalmol 1984;102(8):1232-5.

9) Friedland JA, Lalonde DH, Rohrich RJ. An evidence-based approach to blepharoplasty. Plast Reconstr Surg 2010;126(6):2222-9.

10) Shao C, Fu Y, Lu L, Chen J, Shen Q, Zhu H, et al. Dynamic changes of tear fluid after cosmetic transcutaneous lower blepharoplasty measured by optical coherence tomography. Am J Ophthalmol 2014; 158(1):55-63.e1.

11) Ozsoy Z, Kul Z, Bilir A. The role of cannula diameter in improved adipocyte viability: a quantitative analysis. Aesthet Surg J 2006;26(3): 287-9.

12) Huss FR, Kratz G. Adipose tissue processed for lipoinjection shows increased cellular survival in vitro when tissue engineering principles are applied. Scand J Plast Reconstr Surg Hand Surg 2002;36(3):16671.

13) Yuksel E, Weinfeld AB, Cleek R, Wamsley S, Jensen J, Boutros S, et al. Increased free fat-graft survival with the long-term, local delivery of insulin, insulin-like growth factor-I, and basic fibroblast growth factor by PLGA/PEG microspheres. Plast Reconstr Surg 2000;105(5):1712-20.

14) Chen Y, Wang W, Li J, Yu Y, Li L, Lu N. Fundus artery occlusion caused by cosmetic facial injections. Chin Med J (Engl) 2014;127(8): $1434-7$. 
15) Egido JA, Arroyo R, Marcos A, Jiménez-Alfaro I. Middle cerebral artery embolism and unilateral visual loss after autologous fat injection into the glabellar area. Stroke 1993;24(4):615-6.

16) Wever I, Hwang S, Choroomi S, Mooney W. Delayed mental nerve neuralgia following chin augmentation. Case Rep Otolaryngol 2013;2013:860634.

17) Alam M, Arndt KA, Dover JS. Severe, intractable headache after injection with botulinum a exotoxin: report of 5 cases. J Am Acad Dermatol 2002;46(1):62-5.

18) Khawaja HA, Hernandez-Perez E. Botox in dermatology. Int J Dermatol 2001;40(5):311-7.

19) Ozgur OK, Murariu D, Parsa AA, Parsa FD. Dry eye syndrome due to botulinum toxin type-A injection: guideline for prevention.
Hawaii J Med Public Health 2012;71(5):120-3.

20) Coleman SR; Plastic Surgery Educational Foundation DATA Committee. Cross-linked hyaluronic acid fillers. Plast Reconstr Surg 2006;117(2):661-5.

21) Böhler K, Müller E, Huber-Spitzy V, Schuller-Petrovic S, Knobler $\mathrm{R}$, Neumann R, et al. Treatment of traumatic tattoos with various sterile brushes. J Am Acad Dermatol 1992;26(5 Pt 1):749-53.

22) Bowler PG. The 10(5) bacterial growth guideline: reassessing its clinical relevance in wound healing. Ostomy Wound Manage 2003; 49(1):44-53.

23) Urioste SS, Arndt KA, Dover JS. Keloids and hypertrophic scars: review and treatment strategies. Semin Cutan Med Surg 1999;18(2): 159-71. 